\title{
Аналітичний огляд інформаційних технологій, що використовуються в юридичній діяльності
}

\author{
Сергій Котелевець ${ }^{*}$; ; Наталя Клунко ${ }^{\text {B }}$ \\ А Державний університет телекомунікацій, Навчально-науковий інститут Інформаційних технологій, Інженерія програмного забезпечення, \\ вул. Солом'янська, 7, м. Київ, 03110, Україна \\ в Директор “ПРОФІКОНСАЛТИНГ”, м. Київ, Україна
}

Received: December 10, 2020 | Revised: December 22, 2020 | Accepted: December 31, 2020

DOI: $10.33445 / s d s .2020 .10 .6 .17$

\begin{abstract}
Анотація
У статті наведений аналітичний огляд інформаційних технологій, що використовуються в юридичній діяльності. Інформаційні системи, які формують практичні підстави для використання інформаційних технологій, автором класифіковані в такий спосіб: інформаційно-довідкові системи; інформаційно-логічні системи; автоматизовані робочі місця; експертні системи. Автором доведено, що використання цих технологій дозволяє вирішувати масу поточних проблем, прискорювати збір і пошук інформації, зберігати великі масиви даних, проводити експертизи і аналіз статистичної інформації, підвищуючи, тим самим, ефективність юридичного процесу.
\end{abstract}

Ключові слова: інформаційні технології, юридична діяльність, класифікація, система, пошук інформації, штучний інтелект.

\section{Постановка проблеми}

Рішення сучасних проблем управління суспільством безпосередньо пов'язано 3 розвитком інформаційних технологій. Комп'ютерна техніка і високотехнологічні способи обробки інформації стали невід'ємними компонентами людської діяльності. Еволюція знань про природу інформації, закономірності ї̈ використання, а також зміни характеру суспільства в умовах застосування телекомунікаційних технологій на рубежі 60-70-х рр. минулого століття, сформували нову міждисциплінарну галузь знань - інформатику.
Більш, ніж піввікова еволюція людської діяльності в сфері інформаційних систем сприяла масштабній інформатизації в усіх сферах людської діяльності, в тому числі і в практиці юридичної діяльності.

Необхідність зберігання величезного масиву інформації у вигляді нормативноправових документів, можливість швидкого пошуку документів, проведення експертиз, обробка юридичної інформації призвели до використання інформаційних технологій, що дозволяють вирішувати названі завдання.

\section{Аналіз останніх досліджень та публікацій}

Дослідженню питань, пов'язаних 3 використанням інформаційних технологій в юридичній діяльності присвятили свої роботи такі вчені, як В. Г. Іванов [8], Н. Є. Філіпенко [11], В. Г. Хахановський [1], О.О.Чернишова [13] та ін.

На думку О. О. Чернишової, визначальним

\author{
аспектом юридичної діяльності $\epsilon$ \\ інформаційний, тому впровадження \\ комп'ютерних технологій у юридичний \\ процес $€$ пріоритетним серед сукупності \\ різних технологічних та організаційних \\ рішень у правовій сфері [13]. \\ Дослідники вказують на те, що однією 3
}

\footnotetext{
* Corresponding author: магістрант, e-mail: kotelewetz.sergei@gmail.com
} 
найважливіших особливостей сьогодення $\epsilon$ перехід розвинених країн світу від постіндустріального до інформаційного суспільства, що викликає необхідність вжиття невідкладних заходів із впровадження інформаційних і комунікаційних технологій в ті сфери людського буття, в яких це необхідно. Саме такою сферою слід визнати юридичну та правоохоронну діяльність [3].
Вчені зазначають, що сьогодні в українському правовому полі практично немає такого виду юридичної діяльності, де 6 не використовувалися комп'ютеризація, комп'ютерні технології та Інтернет. Автоматизація багатьох суспільних процесів набуває шалених обертів. Стосується це і юридичної професії [12].

\section{Постановка завдання}

У той же час стрімкий розвиток цих технологій, поява нових видів інформатизації юридичної діяльності актуалізує подальші дослідження у цьому напрямі.
Таким чином, метою статті є дослідження інформаційних технологій, які нині використовуються в юридичній діяльності.

\section{Виклад основного матеріалу}

XXI століття - століття інформатизації і комп'ютеризації, коли інформація є таким же ресурсом, як трудові, матеріальні та енергетичні ресурси. В Україні основу їі правового статусу визначає Закон України “Про інформацію», в якому зазначається, що “інформація - це будь-які відомості та/або дані, які можуть бути збережені на матеріальних носіях або відображені в електронному вигляді" [6].

Інформація - найцінніший ресурс поряд з такими традиційними видами ресурсів, як нафта, газ, корисні копалини та ін., відповідно, процес ії переробки, за аналогією 3 процесами переробки матеріальних ресурсів, можна сприймати як технологію. Як зазначається у Законі України “Про Національну програму інформатизації" інформаційна технологія - це цілеспрямована організована сукупність інформаційних процесів 3 використанням засобів обчислювальної техніки, що забезпечують високу швидкість обробки даних, швидкий пошук інформації, розосередження даних, доступ до джерел інформації незалежно від місця їх розташування [7].

Відповідно процес застосування інформаційних технологій реалізується за допомогою "засобів обчислювальної техніки”, які дозволяють обробляти інформацію. у цьому контексті зазначимо, що Закон України “Про захист інформації в інформаційно-телекомунікаційних системах" наголошує на тому, що інформаційною (автоматизованою) системою $\epsilon$ організаційно-технічна система, В якій реалізується технологія обробки інформації 3 використанням технічних i програмних засобів [5].

Таким чином аналіз наведених нормативно-правових актів дає змогу стверджувати, що практична реалізація інформаційних технологічних рішень відбувається завдяки застосуванню інформаційних автоматизованих систем, відповідно огляд інформаційних технологій, що використовуються в юридичній діяльності, має орієнтуватися на визначення типології інформаційних систем, що використовуються в юридичній практиці.

Звернення до наукової літератури дає можливість виділити наступні інформаційні системи, що використовуються в юридичній сфері:

автоматизовані інформаційно-довідкові системи (АІДС);

автоматизовані інформаційно-логічні системи (АІЛС);

автоматизовані робочі місця (АРМ);

експертні системи (ЕC) [9].

Розглянемо ці системи детальніше.

1) АІCC - це системи, що працюють в 
інтерактивному режимі і призначені для збору, систематизації, зберігання та пошуку інформації в конкретній галузі знань. Одним з основних напрямків професійної юридичної діяльності є довідкова інформаційно-правова робота, пов'язана з пошуком, обробкою, систематизацією та використанням правової інформації. 3 появою персональних комп'ютерів довідкова робота вийшла на якісно новий рівень, основним їі інструментом стали електронні довідкові правові системи (ДПС), за допомогою яких можна швидко знайти будь-яку інформацію правового характеру.

Як зазначає з цього приводу В. Г. Іванов, значення ефективної системи поширення правової інформації для сучасного цивільного суспільства важко переоцінити. Стає очевидним, що жодна реформа економічного і політичного устрою В країні В принципі неможлива без доступу мільйонів громадян і сотень тисяч підприємств до правової інформації [8], оскільки згідно з Законом України “Про інформацію" “ніхто не може обмежувати права особи у виборі форм і джерел одержання інформації, за винятком випадків, передбачених законом" [6].

Найбільш поширеними у галузі права $\epsilon$ пошукові системи “Ліга", “Законодавство”, “Сервер Верховної Ради України", “Сервер законодавчих актів України на Trifle.Net" (відомий також як база законодавства на сервері Арех).

Ці пошукові системи мають власні достоїнства і недоліки, проте, в цілому, забезпечують надійний i швидкий пошук правової інформації. При цьому в юридичній практиці дані системи доцільно використовувати в комплексі, тому що в цілому всі ДПС в чомусь доповнюють одна одну.

До цього класу систем можна віднести також реєстри юридичної інформації, які надають доступ до будь-якої юридичної інформації, що стосується кримінальних проваджень, судових рішень, розпорядників та одержувачів бюджетних коштів, ліцензій на користування радіочастотним ресурсом України т. ін. [4].

2. Більш складними інформаційними системами $\epsilon$ інтелектуальні системи та технології, що засновані на ідеології штучного інтелекту і дозволяють вирішувати логічні завдання. АІЛС надає користувачеві можливість не тільки виконувати пошук правової інформації, але і вирішувати завдання шляхом виконання спеціальних логічних процедур.

Прикладами такої системи може бути програма "PINGUIN-IP" - відкритий графічний інструментальний засіб для обробки та аналізу зображень (призначена для проведення відеофоноскопічних експертних досліджень).

3. Автоматизоване робоче місце (АРМ) це предметно-орієнтована автоматизована система безпосередньо на робочому місці фахівця, призначена для автоматизації його професійної діяльності. АРМ будь-якого інформаційного працівника має відповідати таким вимогам: адаптація на користувача і проблемна орієнтація на завдання конкретного фахівця [8]. АРМ призначені для автоматизації планування роботи, контролю строків виконання, руху службових документів, методичного забезпечення професійної діяльності, включаючи автоматизацію процесу складання стандартних документів.

Як приклад автоматизованих робочих місць, які відповідають вимогам конкретних юридичних спеціалізацій, можна привести автоматизоване робоче місце експертакриміналіста “EXPAD” на базі персонального комп'ютера, що забезпечує введення фонограм у пам'ять ПК та проведення їх криміналістичного дослідження [8].

Також прикладом такої системи $\epsilon$ "Автоматизоване робоче місце юриста (адвоката)" - база даних справ і договорів в роботі, планувальник робочого часу, інструмент для складання звітності та автоматизованого складання процесуальних документів. Ця система надає адвокату наступні можливості: ведення журналу договорів з клієнтами; база даних: справи у провадженні і в архіві, стадії справи, позови (злочини), учасники, завдання, слідчі дії та судові засідання, платежі по справах; 
відображення статистики у справах як по одному користувачеві, так і по всій базі даних; складання звітів за інформацією з бази даних; автоматизоване складання документів: використання даних 3 бази даних для автоматизованого створення основ [2].

Також до систем цього класу можна віднести систему документообігу, наприклад, Система документообігу суду, що являє собою автоматизовану систему документообігу суду, сукупність комп'ютерних програм і відповідних програмно-апаратних комплексів, що входять до складу Єдиної судової інформаційної системи та забезпечують виконання завдань, визначених Положенням про автоматизовану систему документообігу суду, в тому числі таких як: функціонування документообігу суду та органів системи правосуддя; обмін інформацією між ними та з іншими органами державної влади; обмін 3 єдиною централізованою базою даних судової влади; оприлюднення інформації за допомогою офіційного веб-порталу судової влади України; захист інформації від несанкціонованого доступу тощо [10].

4. Найбільш перспективними та, мабуть, найбільш затребуваними в юридичній діяльності, $€$ сучасні експертні системи. Експертна система являє собою найбільш складну автоматизовану інформаційну систему.

Під експертними правовими системами, як i експертними системами іншого призначення, розуміється система штучного інтелекту, що включає в себе базу знань, правила виведення і механізм виведення, тобто “Машину виведення". Ці експертні системи набули широкого поширення i застосовуються в правоохоронній діяльності. Це сталося через здатність систем розпізнавати кримінальну ситуацію, знаходити можливі варіанти їі розслідування, давати практичні рекомендації.

Дана система, взаємодіючи з людиною на природній мові, обробляє символьну інформацію і використовує неповні дані для побудови логічних висновків, причому знання відділені від обслуговуючих їх програмних засобів і вводяться в систему описовим способом. Дані системи дозволяють уникнути не тільки технічної, а й інтелектуальної роботи людей з інформацією, відповідно багаторазово підвищують продуктивність праці за рахунок збільшення швидкості обробки неструктурованої інформації, однак більш складна в експлуатації і не позбавлена від помилок [9].

Основні структурні елементи експертної системи - база знань (факти і правила); механізм логічних висновків (логічні висновки), призначений для користувача інтерфейс, модуль придбання знань (отримання даних від експерта), модуль відповідей і пояснень (висновок). При цьому всі системи, засновані на знаннях, підрозділяються на вирішальні завдання аналізу і синтезу. Здійснюючи інформаційну діяльність, судовий експерт $\epsilon$ вільним у виборі методів дослідження, методик проведення судових експертиз, що також актуалізує використання досліджуваних систем [11].

Однією з перших юридичних експертних систем була JUDITH (1975р.), розроблена в Гейдельберзькому та Дармштадському університетах, яка дозволяє юристам отримувати експертні висновки у цивільних справах. База знань системи складається 3 передумов і виконавчих файлів, які вказують на взаємини, що існують між наборами передумов. JUDITH також була інструментом вивчення юридичних міркувань.

LEGAL ANALYSIS SYSTEM допомагає адвокатам проводити юридичний аналіз справ про умисну образу дією. Правові знання теорії і факти справи подаються у вигляді семантичних мереж. Система надає свої висновки, включаючи логіку, на якій вони засновані. Вона обґрунтовує свої висновки посиланнями на судові рішення і допоміжні законодавчі документи. Ця система була розроблена В Массачусетському технологічному інституті.

SARA допомагає юристам аналізувати рішення, виходячи 3 дискреційних норм. Користувач повідомляє системі фактори і їх значення, які $€$ важливими для рішення. Система приписує ваги всім чинникам так, 
щоб пояснити якомога більше прийнятих рішень. Фактори і рішення подаються у вигляді фреймів. Для обчислення ваг використовується ітеративний кореляційний метод.

Shyster надає консультації в сфері прецедентного права, які були вказані юристами-експертами. Ця система реалізує простий, прагматичний підхід, при якому корисність системи оцінюється не в тій мірі, в якій вона імітує підхід адвоката до правової проблеми, а за якістю її прогнозів і аргументів.

Крім того, існує ще ціла низка юридичних експертних систем. Так, наприклад, LDS допомагає експертам-юристам врегулювати позови про відшкодування збитків і компенсації за збитки, пов'язані з випуском дефектної продукції тощо; DSCAS допомагає аналізувати юридичні аспекти позовів про відшкодування додаткових витрат, які, наприклад, пов'язані з тим, що фізичні умови на місці передбачуваного будівництва відрізняються від зазначених у контракті; TAXAMAN-I і TAXAMAN-II спеціалізується на податковому праві Великобританії; LRS спеціалізується на договірному праві; Rand Project моделює процес прийняття рішень у цивільному процесі; TAXADVISER і EMYCIN використовуються при плануванні федерального оподаткування; C-Clips використовується при кодифікації Цивільного кодексу Луїзіани [9].

Дані експертні системи вирішували і продовжують вирішувати найважливіші питання юридичної практики і виконують функції:

1) усунення суперечностей з актами вищої юридичної сили;

2) усунення внутрішніх суперечностей та прогалин акту;

3) формування ради щодо прийняття рішення в конкретній юридичній ситуації.

Сучасною експертною системою, яка користується попитом в Україні, є система

\author{
“Автоекс", що призначена для використання \\ в експертних дослідженнях наїздів \\ транспортних засобів на пішоходів.
}

Система в режимі діалогу вирішує вісім питань, пов'язаних з наїздом на пішохода. Експертна система забезпечує високий рівень автоматизації експертного дослідження. У ній автоматизовано більшість операцій: експертний аналіз вихідних даних, вибір ходу дослідження, виконання розрахунків, складання висновку, формулювання висновку 3 наступною роздруківкою. За допомогою системи можна отримати відповіді на питання, що стосуються визначення чисельних значень різних параметрів дорожньо-транспортної пригоди: швидкість автомобіля, його зупинний шлях, видалення автомобіля від місця наїзду в конкретний момент часу і т. ін. Вирішуються також i розрахунково-логічні питання: наприклад, наявність або відсутність у водія транспортного засобу технічної можливості запобіти наїзду на пішохода. На здійснення однієї експертизи витрачається в середньому п'ять хвилин: три хвилини на введення даних і дві - на дослідження і друк. Система дозволяє досліджувати наїзди транспортних засобів на перешкоду, а також зіткнення транспортних засобів.

У системі передбачений контроль правильності введення вхідних даних. Експертний висновок, що автоматично формується системою, складається 3 текстової частини, математичних формул для обчислень параметрів інциденту, необхідних розрахункових таблиць.

у цілому необхідно зазначити високу ефективність використання системи "Автоекс" завдяки засобам автоматизації та великій кількості авто технічних експертиз, що проводяться останнім часом [1].

Безумовно, що спектр використання даних систем в XXI столітті буде суттєво розширений за рахунок подальшого впровадження систем “штучного інтелекту в юридичну діяльність".

\section{Висновки}

Активний розвиток інформаційних телекомунікаційних технологій викликав їх широке застосування в різних сферах діяльності. Одним з напрямів використання 
інформаційних технологій $\epsilon$ юридична діяльність. Застосування інформаційних технологій в різних сферах, пов'язаних 3 юридичним профілем дозволяє прискорювати збір і пошук інформації, зберігати великі масиви даних, проводити експертизи і аналіз статистичної інформації, підвищуючи, тим самим, ефективність юридичного процесу.

Інформаційні системи, які формують практичні підстави для використання інформаційних технологій, класифіковані в такий спосіб: інформаційно-довідкові системи; інформаційно-логічні системи; автоматизовані робочі місця; експертні системи. Інформаційно-довідкові системи використовуються в інтерактивному режимі і призначені для збору, систематизації, зберігання та пошуку інформації; інформаційно-логічні системи засновані на технологіях штучного інтелекту, дозволяючи тим самим вирішувати різноманітні логічні завдання юридичної практики; автоматизовані робочі місця орієнтовані на предметну специфіку професійної діяльності на робочому місці (судді, адвоката, слідчого); експертні системи, також як і інформаційнологічні, орієнтовані на технології штучного інтелекту, включають в себе, крім бази даних, комплект правил і механізмів, що дозволяють визначити стан досліджуваного об'єкта або явища, прийти до логічного вирішення або надати рекомендації щодо вибору дії (“Балекс" (балістична експертиза), “Кортик” (експертиза холодної зброї)).

Таким чином інформаційні технології в юридичній діяльності відрізняються масштабним характером, що пояснюється широким спектром ситуацій, де їх використання призводить до підвищення якості юридичної, законодавчої та правоохоронної діяльності.

\section{Список використаних джерел}

1. Автоматизація судових експертних досліджень / Хахановський В. Г. // Інформація і право, 2013. - № 2(8). - С. 92-98.

2. APM юриста (адвоката). - URL : https://allsoft.ua/software/vendors/technicalsovt-group/arm-yurista-advokata/

3. Білоус В. В. Про запровадження інформаційнихі комунікаційних технологій у навчальний процес з криміналістики / В. В. Білоус // Проблеми законності : акад. зб. наук. пр. -Х.: Нац. ун-т “Юрид. акад. України ім. Ярослава Мудрого”, 2012. - Вип. 118. - С. 166-175.

4. Відкриті реєстри та бази даних України. URL: https://infobox.prozorro.org/articles/ perelik-vidkritih-reyestriv-ta-baz-danih-ukrajini

5. Закон України “Про захист інформації в інформаційно-телекомунікаційних системах" // Відомості Верховної Ради України (ВВР), 1994, № 31, ст. 286

6. Закон України “Про інформацію” // Відомості Верховної Ради України (ВВР), 1992, № 48, ст. 650.

7. Закон України “Про Національну програму інформатизації" // Відомості Верховної Ради України (ВВР), 1998, № 27-28, ст. 181.

8. Іванов В. Г. Правова інформація та комп'ютерні технології в юридичній діяльності: Навч. посіб. / В.Г. Іванов, С.М. Іванов, В.В. Карасюк та ін.; за заг. ред. В.Г. Іванова. - Х.: Право, 2010. - 240 с.

9. Казиев В. М. Основы правовой информатики и информатизации правовых систем. Учебное пособие / Казиев В. М., Казиев К. В., Казиева Б. В. - М.: Инфра-М, Вузовский учебник. 2017. - 336 с.

10. Положення про автоматизовану систему документообігу суду від 26.11.2010 № 30. URL: https://zakon.rada.gov.ua/rada/show/ vr030414-10\#Text

11. Філіпенко Н. Є. Інформаційні системи в судово-експертній діяльності // Теорія та практика судової експертизи i криміналістики, 2018. - Вип. 18. - С. 271-281.

12. Фрончко В. В. До питання про цифрову юриспруденцію / В. В. Фрончко // Актуальні проблеми правознавства,2019. - Вип. 2 (18). - С. 144-149.

13. Чернишова О. О. Інформаційне забезпечення нотаріальної діяльності / О. О. Чернишова // Правова система: теорія і практика, 2014. - №4. - С. 83-86. 


\title{
Аналитический обзор информационных технологий, используемых в юридической деятельности
}

\author{
Сергей Котелевец * А; Наталья Клунко ${ }^{\text {В }}$ \\ *Corresponding author:магистрант, e-mail: kotelewetz.sergei@gmail.com \\ А Государственный университет телекоммуникаций, Учебно-научный институт информационных технологий, \\ Инженерия программного обеспечения, ул. Соломенская, 7, г. Киев, 03110, Украина \\ в Директор "ПРОФИКОНСАЛТИНГ", г. Киев, Украина.
}

\begin{abstract}
Аннотация
В статье приведен аналитический обзор информационных технологий, используемых в юридической деятельности. Информационные системы, которые формируют практические основания для использования информационных технологий, автором классифицированы следующим образом: информационно-справочные системы; информационно-логические системы; автоматизированные рабочие места; экспертные системы. Автором доказано, что использование этих технологий позволяет решать массу текущих проблем, ускорять сбор и поиск информации, хранить большие массивы данных, проводить экспертизы и анализ статистической информации, повышая, тем самым, эффективность юридического процесса.
\end{abstract}

Ключевые слова: информационные технологии, юридическая деятельность, классификация, система, поиск информации, искусственный интеллект.

\section{Analytical overview of information technologies used in legal activities}

\author{
Sergey Kotelevets * A; Nataliya Klunko ${ }^{\text {B }}$ \\ *Corresponding author: master's student, e-mail: kotelewetz.sergei@gmail.com \\ A State University of telecommunications, educational and Scientific Institute of Information Technologies, software engineering, \\ 7, Solomenskaya str., Kyiv, 03110, Ukraine

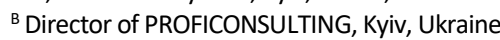

\begin{abstract}
The article provides an analytical review of information technology used in legal activities. Information systems that form a practical basis for the use of information technology, the author is classified as follows: information and reference systems; information and logic systems; automated workplaces; expert systems. The author proves that the use of these technologies allows to solve a lot of current problems, speed up the collection and retrieval of information, store large data sets, conduct examinations and analysis of statistical information, thereby increasing the efficiency of the legal process.
\end{abstract}

Keywords: information technologies, legal activity, classification, system, information retrieval, artificial intelligence.

\section{References}

1. Khakhanovskyi V. H. (2013) Avtomatyzatsiia sudovykh ekspertnykh doslidzhen. Informatsiia i pravo, № 2(8). S. 92-98.

2. ARM yurysta (advokata). - URL : https://allsoft.ua/software/vendors/technicalsovt-group/arm-yurista-advokata/

3. Bilous V. V. (2012) Pro zaprovadzhennia informatsiinykh i komunikatsiinykh tekhnolohii u navchalnyi protses z kryminalistyky. Problemy zakonnosti : akad. zb. nauk. pr. Kharkiv: Nats. un-t "luryd. akad. Ukrainy im. Yaroslava Mudroho", Vyp. 118. S. 166-175.

4. Vidkryti reiestry ta bazy danykh Ukrainy. - URL: https://infobox.prozorro.org/articles/ perelik- 
vidkritih-reyestriv-ta-baz-danih-ukrajini

5. Pro zakhyst informatsii $v$ informatsiinotelekomunikatsiinykh systemakh: Zakon Ukrainy. Vidomosti Verkhovnoi Rady Ukrainy (VVR), 1994, № 31, st. 286.

6. Pro informatsiiu: Zakon Ukrainy. Vidomosti Verkhovnoi Rady Ukrainy (VVR), 1992, № 48, st. 650 .

7. Pro Natsionalnu prohramu informatyzatsii: Zakon Ukrainy. Vidomosti Verkhovnoi Rady Ukrainy (VVR), 1998, № 27-28, st. 181.

8. Ivanov V. H. Pravova informatsiia ta kompiuterni tekhnolohii $\mathrm{v}$ yurydychnii diialnosti: Navch. posib. / V.H. Ivanov, S.M. Ivanov, V.V. Karasiuk ta in.; za zah. red. V. H. Ivanova. Kharkiv: Pravo, 2010. 240 s.

9. Kazyev V. M. Osnovb pravovoi ynformatyky y ynformatyzatsyy pravovыkh system. Uchebnoe posobye / Kazyev V. M., Kazyev K. V., Kazyeva B. V. Moskva: Ynfra-M, Vuzovskyi uchebnyk. 2017. $336 \mathrm{~s}$.

10. Polozhennia pro avtomatyzovanu systemu dokumentoobihu sudu vid 26.11.2010 № 30. URL: https://zakon.rada.gov.ua/rada/show/ vr030414-10\#Text

11. Filipenko N. Ye. (2018) Informatsiini systemy v sudovo-ekspertnii diialnosti. Teoriia ta praktyka sudovoi ekspertyzy i kryminalistyky, Vyp. 18. S. 271-281.

12. Fronchko V. V.(2019) Do pytannia pro tsyfrovu yurysprudentsiiu. Aktualni problemy pravoznavstva, Vyp. 2 (18). S. 144-149.

13. Chernyshova O. O. (2014) Informatsiine zabezpechennia notarialnoi diialnosti. Pravova systema: teoriia i praktyka, №4. S. 83-86. 